\title{
COMPARATIVE EVALUATION OF WATER COLLECTION METHODS USING MULTICRITERIA DECISION MAKING ANALYSIS
}

\author{
${ }^{\dagger}$ Mariolakos D. ${ }^{1}$ \\ ${ }^{1}$ Geologist, MSc.
}

\begin{abstract}
The necessity for the improvement and change of the way to collect water is of great need, especially nowadays that water tends to become a limited natural resource. The aim of this project is to study and evaluate an alternative water collection method, the artificial recharge, and compare it with the conventional established method of dam construction. The evaluation tool is a Multi-Criteria Decision Making Analysis. Multi-Criteria Analysis evaluates these two methods based on certain common criteria. More precisely, each method is examined multi-dimensionally, so that all aspects and possible problems of the application of these methods are studied.
\end{abstract}

Key words: water collection method, artificial recharge, dam construction.

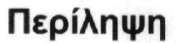

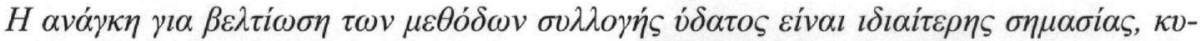

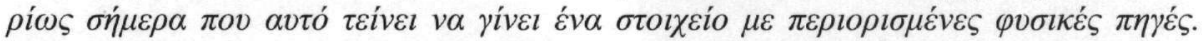

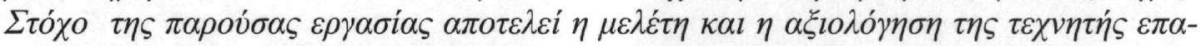

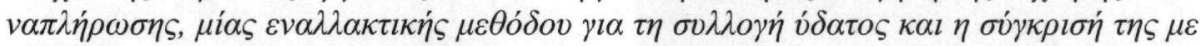

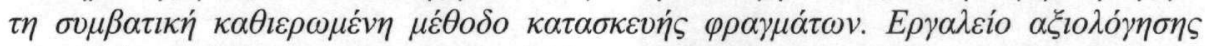

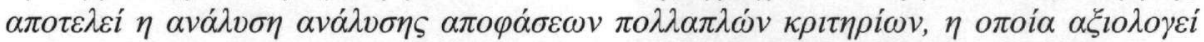

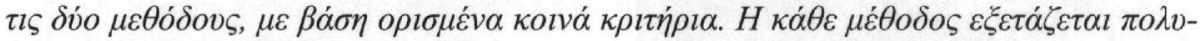

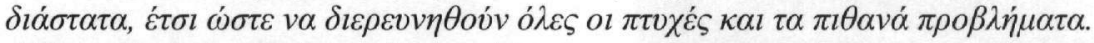

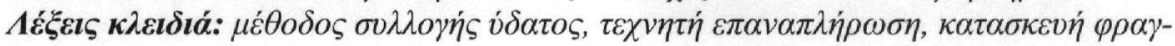
$\mu \dot{\alpha} \tau \omega v$.

\section{Introduction - The Multi-Criteria Decision Making Analysis}

It's worldwide known that the natural resources, that are available to the human being, have been diminishing rapidly and water is the most significant one. Besides, it is also known that the climate is changing periodically, therefore there are several periods of drought of either longer or shorter duration. The drought that takes place in this period is called the "Sahel drought". Based on these general conclusions, it is obviously quite easy to understand that it is imperative to constantly improve the water collection methods. During that process, one has to take into consideration all the

${ }^{\dagger}$ Dimitris passed away on 10/11/2003 after a road accident (16/10/2003), when he was just 31 years old. 
environmental parameters that might be linked with the application of the proposed method. The aim of this project is to evaluate and examine holistically these two water collection methods - the widely familiar method of constructing a dam and the method of artificial recharge. Unfortunately, the latter one has not been widely known, since the occasions of its application are just a few. For this evaluation the method of Multi-Criteria Decision Making Analysis has been used.

Generally, Multi-Criteria Analysis is a very important and powerful tool which has a wide application in environmental management problems and provides the optimal solution. In most cases the finding and the evaluation of the optimal solution is a complicated process. A one dimensional study of a problem does not lead to the best possible solution. Therefore, it is necessary to examine a problem based on certain common criteria. It is significant to choose the most appropriate criteria in order to draw the best possible conclusions. The type of criteria depends: (a) directly on the kind of problem which is going to be solved and on its special features and (b) indirectly, since the specific problem is being influenced or influences the attitude of several groups which are interested and, maybe, they have got something in common with the application of the method. The simultaneous examination of various alternative or suggested scenarios, based on certain properly chosen criteria, which aim at the best possible solution, is the Multi-Criteria Analysis.

\section{Criteria Selection and Classification}

The selection of these criteria should be:

- Complete multi dimensional in other words the criteria should examine the problem from all different aspects.

- Functional, meaning that all the criteria should be graded with specific for each alternative scenario grading and be classified in a specific scale of grades.

- Done in such a way to avoid contradiction between criteria.

The criteria which have been selected for the examination and the comparison of the final choice of the water collection method are classified into four groups and are the following:

\section{SOCIAL CRITERIA}
i) Social Approval
ii) Concordance with the existing Legislation
iii) New Jobs opportunities
iv) Application of possible Legislative Priorities

\section{ENVIRONMENTAL CRITERIA}
i) Environmental consequences
ii) Aesthetics
iii) Potential Dangers

\section{FINANCIAL CRITERIA}
i) The Initial Cost of the Project
ii) Operational Cost-Maintenance Cost
iii) Land/Property Requirements (Land acquisition cost)

\section{FUNCTIONAL AND TECHNICAL CRITERIA}
i) Functionality
ii) Life Span
iii) Existing Experience - Reliability 
v) Flexibility

Further on, there is a detailed description of all the above mentioned criteria of each group.

\subsection{A Detailed Description of Each Group's individual Criteria}

\subsubsection{Social Criteria}

These criteria evaluate the relationship and the impact of each suggested method on the society of the region where it is applied.

\section{i) Social Approval}

It is a very important criterion for each method of making decisions. The social approval of each suggested method depends on several factors, such as the existing water collection method, the level of awareness of the inhabitants about the environmental problems and especially those problems that deal with the lack of water.

\section{ii) Concordance with the Existing Legislation}

By this criterion any existing legislation of the National Planning is taken into consideration as well as the one of the European Union concerning the application of water collection methods. More specifically, in our situation it is the $75 / 440$ Directive of the E.U. concerning the required quality of the surface water which is going to be used for the abstraction of drinking water in the memberstates, as well as the voting of the Council of the $25^{\text {th }}$ February 1992 for the future policy concerning the underground water.

\section{iii) Application of Possible Legislative Priorities}

Based on this criterion we can examine how, through the application of suggested water collection methods, any Legislative Priorities take place which are dictated by not only the National Planning, but also by E.U legislation.

\section{iv) New Jobs opportunities}

The possibility of creating new jobs opportunities is a basic social criterion for the final choice of the suggested applications, moreover when we refer to semi-urban and rural regions.

\subsubsection{Environmental Criteria}

These criteria deal with the question directly, which of the methods being examined has a minimum environmental impact. It should be mentioned that this question has got two parameters:

- One parameter has to do the direct impact of the project on the environment.

- The other parameter has to do with the possibility of operational malfunction.

\section{i) Affecting the Environment}

This criterion basically examines which of the two suggested methods has the minimum environmental impact.

ii) Aesthetics

The aesthetic alterations of the local scenery, caused by the development and function of the suggested methods make up a criterion of great significance which depends on the design of the method. This criterion is directly related to the $2 \mathrm{i}$ criterion (Affecting the Environment) as well as with the public opinion on the environmental efficiency of the method. The criterion of aesthetics usually becomes highly critical when any construction takes place in heavily populated regions. 
This criterion examines the accident possibility factor and the danger factor concerning the exposure to danger of personnel and citizens of the region, while the method is operating, but it mainly refers to possible accidents or any possible malfunctions.

\subsubsection{Economic Criteria}

\section{i) Initial (Capital) Cost of the Project}

The criterion of the Initial Cost is one of the most critical in most environmental management problems. It becomes even more critical in those situations which part of the initial cost is shifted to the citizens, if the project is self financed.

ii) Operational Cost-Maintenance Cost

This criterion refers to all the expenses of operation and maintenance. This criterion is very significant for the final approval of the work because these expenses are substantially transferred to the inhabitants whom the work serves.

\section{iii) Land/Property Requirements (Land acquisition cost)}

This criterion is more significant to cases where there is either lack of land or the value of the land is very high (e.g. the islands).

\subsubsection{Functional and Technical Criteria}

The criteria of this group examine the functionality of the suggested scenarios as well as technical characteristics which are important for their normal and constant operation.

\section{i) Functionality}

Within this criterion the following are included and examined:

- Normal and constant operation.

- Demands of specialized personnel.

- Easy to maintain.

- Easy to operate.

- Durability of the suggested method.

- The expected time life of each method.

The "sum" of the above-mentioned factors defines the functionality of the method.

ii) The Existing Experience - Reliability

Any existing experience of the application of a corresponding method and system plays an important role to the evaluation of the suggested water collection methods. Especially when new methods are proposed (e.g. artificial recharge), it is important for their future adaptation and application.

\section{iii) Adjustability to Local Conditions}

The normal and successful function and application of each method depends directly on the suggested region's particular characteristics. All the physical-geological characteristics of the region should be included in the study.

iv) Flexibility

With this criterion every suggested method is being examined how it can adjust to possible changes of the quantities of water which it can accept. The criterion is very important when there are significant climatic changes influencing directly the annual water fluxes. 
In a following chapter each criterion is analyzed according to each suggested scenario's special characteristics.

\section{The System of Taking Decisions by using an Overall/ Holistic Function}

Based on the above mentioned Multi-Criteria Decision Making System analysis, the comparative evaluation of the alternative scenario - choices takes place according to the following stages/steps:

\section{- $\mathbf{1}^{\text {st }}$ Step}

In this first step, the groups of the criteria are set, where each group consists of a series of criteria which are described in the second step. Moreover, at this point the significance of each group of criteria is defined, which expresses the relevant meaning of each group for each examined scenario. Afterwards, based on the groups of the criteria and the corresponding significance of theirs, the final adding sequence is produced. The sum of the significance of each group of criteria is $100 \%$. It is quite understood that decision making using the multi-criteria analysis is quite subjective, since the significance of the criteria depends directly on the analyser. In the following table (Table 1) the factors of significance of each group of criteria are presented.

Table 1 - The Groups of Criteria and the Significance Factors

\begin{tabular}{|c|c|c|}
\hline & Description & Significance Factor \\
\hline $\mathrm{OK}_{1}$ & Social Criteria & 0.25 \\
\hline $\mathrm{OK}_{2}$ & Environmental Criteria & 0.30 \\
\hline $\mathrm{OK}_{3}$ & Economic Criteria & 0.25 \\
\hline $\mathrm{OK}_{4}$ & Functional - Technical Criteria & 0.20 \\
\hline
\end{tabular}

Consequently, the overall/holistic function is the following:

$$
f=0.25 O K_{1}+0.30 O K_{2}+0.25 O K_{3}+0.20 O K_{4}
$$

\section{- $\quad 2^{\text {nd }}$ Step}

In the second step the groups of criteria are "stripped down" to the special criteria they consist of, where by using the proper significance factors, the relevant significance of each criterion is defined. The sum of the significance of the criteria of each group is $100 \%$.

In Table 2, the special characteristics of each group are presented as well as the relevant significance of theirs, in the groups where they belong.

Table 2 - A Table of all the Special Criteria for the Evaluation of all the Alternative Scenarios

\begin{tabular}{|c|c|}
\hline & Criteria \\
\hline $\begin{array}{c}\text { Criterion / Factor of Signifi- } \\
\text { cance }\end{array}$ & SOCIAL - INSTITUTIONAL $(0.25)$ \\
\hline $\mathrm{S}_{1}(\mathbf{0 . 2 5})$ & Concordance with the existing Legislation \\
\hline $\mathrm{S}_{2}(0.30)$ & Application of possible Legislative Priorities \\
\hline $\mathrm{S}_{3}(\mathbf{0 . 3 0})$ & Social Approval \\
\hline $\mathrm{S}_{4}(0.15)$ & New jobs Opportunities \\
\hline & ENVIRONMENTAL (0.30) \\
\hline $\mathbf{E N}_{1}(0.40)$ & Environmental Impact \\
\hline $\mathbf{E N}_{2}(0.30)$ & Aesthetics \\
\hline $\mathrm{EN}_{3}(0.30)$ & Potential Dangers \\
\hline & ECONOMIC (0.25) \\
\hline $\mathbf{E}_{1}(0.40)$ & Initial Cost of Investment \\
\hline
\end{tabular}




\begin{tabular}{|l|c|}
\hline $\mathbf{E}_{\mathbf{2}}(\mathbf{0 . 4 0 )}$ & Operational Cost -Maintenance Cost \\
\hline $\mathbf{E}_{\mathbf{3}}(\mathbf{0 . 2 0 )}$ & Land Acquisition/Property requirements \\
\hline & TECHNICAL - FUNCTIONAL (0.20) \\
\hline $\mathbf{T}_{\mathbf{1}}(\mathbf{0 . 3 0 )}$ & Functionality \\
\hline $\mathbf{T}_{\mathbf{2}}(\mathbf{0 . 3 0}$ & Existing Experience - Reliability \\
\hline $\mathbf{T}_{\mathbf{3}}(\mathbf{0 . 1 5})$ & Adjustability to the Existing Conditions \\
\hline $\mathbf{T}_{\mathbf{4}}(\mathbf{0 . 1 5})$ & Flexibility \\
\hline $\mathbf{T}_{\mathbf{5}}(\mathbf{0 . 1 0}$ & Life Span \\
\hline
\end{tabular}

- $3^{\text {rd }}$ Step

For each special criterion, initially an evaluation of its special characteristics takes place and afterwards it is marked on a scale from 1 to 10 . The scenario which takes the highest marks is therefore the most desirable one.

\subsection{Marking of All the Special Criteria}

Further on, all the tables are presented according to which the marking of all the special criteria takes place.

\section{SOCIAL - INSTITUTIONAL CRITERIA}

$\mathbf{S}_{1}$ : Concordance with the existing Legislation

\begin{tabular}{|l|c|}
\hline Complete Concordance & 10 \\
\hline Partial Concordance & 5 \\
\hline No Concordance due to lack of Legislation & 5 \\
\hline No Concordance & 1 \\
\hline
\end{tabular}

S2: Application of possible Legislative Priorities

\begin{tabular}{|l|c|}
\hline Complete Application & 10 \\
\hline Partial Application & 5 \\
\hline No Application & 3 \\
\hline Opposite to the General Instructions & 1 \\
\hline
\end{tabular}

$\mathbf{S}_{3:}$ Social Approval

\begin{tabular}{|l|c|}
\hline Complete Social Approval & 10 \\
\hline Partial Social Approval & 5 \\
\hline Social Approval due to lack of Environmental Awareness & 3 \\
\hline No Social Approval due to lack of Environmental Awareness & 3 \\
\hline (Unsocial) No Social Approval after the relevant Environmental Awareness & 1 \\
\hline
\end{tabular}

$\mathbf{S}_{\mathbf{4}}$ : Opportunities for New Jobs

\begin{tabular}{|l|c|}
\hline Opportunities for New Jobs at a high degree & 10 \\
\hline Opportunities for New Jobs at a limited degree & 5 \\
\hline No Opportunities for New Jobs at a high degree & 1 \\
\hline
\end{tabular}

\section{ENVIRONMENTAL CRITERIA}

$\mathbf{E N}_{1}$ : Environmental Impact

\begin{tabular}{|l|c|}
\hline Maximum Environmental Impact & 1 \\
\hline Moderate Environmental Impact & 4 \\
\hline Minimum Environmental Impact & 7 \\
\hline
\end{tabular}


$\mathbf{E N}_{2}$ : Aesthetics

\begin{tabular}{|l|c|}
\hline High Aesthetics & 10 \\
\hline Relatively High Aesthetics & 7 \\
\hline Moderate Aesthetics & 4 \\
\hline Negative Aesthetics & 1 \\
\hline
\end{tabular}

$\mathbf{E N}_{3}$ : Potential Dangers

\begin{tabular}{|l|c|}
\hline High Grade & 1 \\
\hline Relatively High Grade & 3 \\
\hline Low Grade & 7 \\
\hline Negligible Grade & 10 \\
\hline
\end{tabular}

\section{ECONOMIC CRITERIA}

$\mathbf{E}_{\mathbf{1}}$ : Initial Cost of Investment

\begin{tabular}{|l|c|}
\hline High Initial Cost & 1 \\
\hline Relatively High Initial Cost & 3 \\
\hline Moderate Initial Cost & 5 \\
\hline Low Initial Cost & 8 \\
\hline Negligible Initial Cost & 10 \\
\hline
\end{tabular}

$\mathbf{E}_{2}$ : Functional Cost -Maintenance Cost

\begin{tabular}{|l|c|}
\hline High Functional Cost & 1 \\
\hline Relatively High Functional Cost & 4 \\
\hline Moderate Functional Cost & 7 \\
\hline Low Functional Cost & 10 \\
\hline
\end{tabular}

$\mathbf{E}_{3}$ : Land/ Property Acquisition

\begin{tabular}{|l|c|}
\hline High Cost for Land acquisition & 1 \\
\hline Relatively High Cost for Land Acquisition & 3 \\
\hline Moderate Cost for Land Acquisition & 7 \\
\hline Low Cost for Land Acquisition & 10 \\
\hline Lack of Land & 1 \\
\hline
\end{tabular}

\section{TECHNICAL - FUNCTIONAL CRITERIA}

$\mathrm{T}_{1}$ : Functionality

\begin{tabular}{|l|c|}
\hline High & 10 \\
\hline Relatively High & 7 \\
\hline Moderate & 5 \\
\hline Low & 3 \\
\hline Very Low & 1 \\
\hline
\end{tabular}

$\mathbf{T}_{2}$ : Existing Experience - Reliability

\begin{tabular}{|l|c|}
\hline High & 10 \\
\hline Relatively High & 7 \\
\hline Moderate & 5 \\
\hline Low & 3 \\
\hline Very Low & 1 \\
\hline
\end{tabular}




\begin{tabular}{|l|c|}
\hline High & 10 \\
\hline Relatively High & 7 \\
\hline Moderate & 5 \\
\hline Low & 3 \\
\hline Very Low & 1 \\
\hline
\end{tabular}

$\mathbf{T}_{4}$ : Flexibility

\begin{tabular}{|l|c|}
\hline High & 10 \\
\hline Relatively High & 7 \\
\hline Moderate & 5 \\
\hline Low & 3 \\
\hline Very Low & 1 \\
\hline
\end{tabular}

$\mathbf{T}_{5}$ : Life Span

\begin{tabular}{|l|c|}
\hline Long Life Span $>70$ years & 10 \\
\hline Average Life Span $30-70$ years & 5 \\
\hline Short Life Span $<30$ years & 1 \\
\hline
\end{tabular}

\section{- $4^{\text {th }}$ Step}

In the fourth step, initially all the characteristics of each special criterion are defined for every alternative scenario and afterwards each criterion is marked according to the tables which were formed in the previous step. This is described in the following tables. At this point we should make clear that the comparative evaluation of the two methods (artificial recharge and dam construction) takes place by taking into consideration those situations that the application of each method takes place under the most ideal conditions. That is, each method is examined either at several regions, or even at the same region, but in cases when the special characteristics of this region allow the successful application of both methods (e.g. the degree of karstification is so high that it allows the successful application of the artificial recharge).

\begin{tabular}{|c|c|c|}
\hline $\begin{array}{c}\text { Criteria of Comparative } \\
\text { Analysis } \\
\end{array}$ & $\begin{array}{c}\text { ELEMENTS CONCERNING THE METHOD OF } \\
\text { ARTIFICIAL RECHARGE }\end{array}$ & Grading \\
\hline \multicolumn{3}{|l|}{ SOCIAL } \\
\hline $\begin{array}{l}S_{1}: \text { Concordance with the } \\
\text { existing Legislation }\end{array}$ & $\begin{array}{l}\text { There is complete concordance with the existing Legislation, } \\
\text { as it is dictated by the voting of the Council of the } 25^{\text {th }} \text { of Feb- } \\
\text { ruary } 1992 \text { for the future policy concerning the underground } \\
\text { water }(95 / \mathrm{C} 49 / 01) \text {. }\end{array}$ & 10 \\
\hline $\begin{array}{l}S_{2}: \text { Application of possible } \\
\text { Legislative Priorities }\end{array}$ & $\begin{array}{l}\text { Complete application of the Legislative Priorities of the voting } \\
(95 / \mathrm{C} 49 / 01) \text { of the European Council concerning the conserva- } \\
\text { tion and increase of quantity of the underground water. }\end{array}$ & 10 \\
\hline$S_{3}:$ Social Approval & $\begin{array}{l}\text { The Social Approval is expected, provided that there will be } \\
\text { constant check of the quality of the water for the recharge. }\end{array}$ & 8 \\
\hline $\begin{array}{l}S_{4}: \text { New Jobs Opportuni- } \\
\text { ties }\end{array}$ & $\begin{array}{l}\text { While applying the method, new personnel of technical ex- } \\
\text { perts will be necessary, such as an operator, a supervisor, } \\
\text { technicians for the change of the filters etc. }\end{array}$ & 5 \\
\hline \multicolumn{3}{|l|}{ ENVIRONMENTAL } \\
\hline $\begin{array}{l}E N_{1}: \text { Environmental im- } \\
\text { pact }\end{array}$ & $\begin{array}{l}\text { Negligible environmental impact, therefore remediation of the } \\
\text { natural environment is possible. }\end{array}$ & 7 \\
\hline$E_{2}:$ Aesthetics & $\begin{array}{l}\text { Affecting the environment, in general, is negligible and there- } \\
\text { fore the aesthetic intervention is also minimal. }\end{array}$ & 8 \\
\hline$E N_{3}:$ Potential Dangers & $\begin{array}{l}\text { Due to the technique of the artificial recharge as well as the } \\
\text { existence of immediate and constant technologically advanced } \\
\text { supervision, the potential dangers are becoming less. }\end{array}$ & 8 \\
\hline
\end{tabular}




\begin{tabular}{|c|c|c|}
\hline ECONOMIC & & \\
\hline $\begin{array}{l}E_{1}: \text { Initial Cost of Invest- } \\
\text { ment }\end{array}$ & $\begin{array}{l}\text { The initial cost for the application of the method of the artifi- } \\
\text { cial recharge is relatively low. }\end{array}$ & 8 \\
\hline $\begin{array}{l}E_{2}: \text { Functional Cost-Cost } \\
\text { of Maintenance }\end{array}$ & $\begin{array}{l}\text { The functional cost of the method consists of: the salaries of } \\
\text { the personnel, energy costs as well as those concerning the } \\
\text { maintenance of the whole construction, e.g. the change of a } \\
\text { filter. }\end{array}$ & 7 \\
\hline $\begin{array}{l}E_{3}: \text { Land/ Property acqui- } \\
\text { sition and Needs }\end{array}$ & $\begin{array}{l}\text { Minimal land acquisition needs at a proper geologically sited } \\
\text { region (e.g. regions of high karstification degree). }\end{array}$ & 10 \\
\hline $\begin{array}{l}\text { TECHNICAL - } \\
\text { FUNCTIONAL }\end{array}$ & & \\
\hline$T_{l}:$ Functionality & High / Efficient Functionality & 9 \\
\hline $\begin{array}{l}T_{2}: \text { Existing Experience - } \\
\text { Reliability }\end{array}$ & $\begin{array}{l}\text { The method of artificial recharge is worldwide known and } \\
\text { reliable, as far as any of its applications is concerned. In } \\
\text { Greece there are only research/ experimental applications. }\end{array}$ & 7 \\
\hline $\begin{array}{l}T_{3}: \text { Adjustability to Local } \\
\text { Conditions }\end{array}$ & $\begin{array}{l}\text { Total adjustability to local conditions, provided that the region } \\
\text { where the method is applied has been chosen after a detailed } \\
\text { geological and technical study. }\end{array}$ & 9 \\
\hline$T_{4}:$ Flexibility & The method is flexible to any periodic changes. & 9 \\
\hline$T_{5}:$ Life Span & Long life span. & 10 \\
\hline
\end{tabular}

\begin{tabular}{|c|c|c|}
\hline $\begin{array}{l}\text { Criteria of Comparative } \\
\text { Evaluation }\end{array}$ & $\begin{array}{l}\text { ELEMENTS CONCERNING THE CONCENTRATION } \\
\text { OF WATER BY CONSTRUCTING A DAM }\end{array}$ & Grading \\
\hline \multicolumn{3}{|c|}{ (6) } \\
\hline $\begin{array}{l}S_{1}: \text { Concordance with the } \\
\text { existing Legislation }\end{array}$ & $\begin{array}{l}\text { There is no specific legislative framework which is dictated } \\
\text { either by the E.U., or by the National Planning, therefore there } \\
\text { is not direct concordance. Concordance is restricted in the } \\
\text { wide subject of trying to increase the water resources }\end{array}$ & 5 \\
\hline $\begin{array}{l}S_{2}: \text { Application of possible } \\
\text { Legislative Priorities }\end{array}$ & $\begin{array}{l}\text { There is no specific Legislative Priority, but the general prior- } \\
\text { ity of maintenance and increase of the quantity of water re- } \\
\text { sources is applied. }\end{array}$ & 7 \\
\hline $\begin{array}{l}S_{3}: \text { Social Approval/ Ac- } \\
\text { ceptance }\end{array}$ & $\begin{array}{l}\text { So far dams are socially accepted. This result mainly from the } \\
\text { inadequate awareness of the public on the environmental prob- } \\
\text { lems related to dam, as well as that the public is unaware of } \\
\text { alternative water collection methods e.g. method of artificial } \\
\text { recharge. }\end{array}$ & 7 \\
\hline $\begin{array}{l}S_{4}: \text { Possibility of New } \\
\text { Posts of Work }\end{array}$ & $\begin{array}{l}\text { Personnel for the function and the supervision of the dam will } \\
\text { be necessary, such as operators, supervisors, technicians, elec- } \\
\text { tricians etc. }\end{array}$ & 7 \\
\hline \multicolumn{3}{|l|}{ ENVIRONMENTAL } \\
\hline $\begin{array}{l}\text { EN }: \text { Environmental Im- } \\
\text { pact }\end{array}$ & Huge Environmental Impacts. Remediation is impossible. & 1 \\
\hline $\mathrm{EN}_{2}:$ Aesthetics & $\begin{array}{l}\text { Affecting the environment in general is important and conse- } \\
\text { quently the aesthetic intervention is also significant. Neverthe- } \\
\text { less, there are measures that should be taken in order not to be } \\
\text { negative. }\end{array}$ & 4 \\
\hline$E N_{3}:$ Potential Dangers & $\begin{array}{l}\text { Potential dangers are possible, due to the complexity of the } \\
\text { method. Nevertheless, if proper measures are taken, like } \\
\text { proper geological planning for site selection, constant and } \\
\text { technologically advanced supervision, then potential dangers } \\
\text { may be reduced. }\end{array}$ & 5 \\
\hline \multicolumn{3}{|l|}{ ECONOMIC } \\
\hline $\begin{array}{l}E_{1}: \text { Initial Cost of Invest- } \\
\text { ment }\end{array}$ & $\begin{array}{l}\text { The initial/capital cost for the investment for the construction } \\
\text { of a dam is very high. }\end{array}$ & 1 \\
\hline $\begin{array}{l}E_{2}: \text { Functional Cost-Cost } \\
\text { of Maintenance }\end{array}$ & $\begin{array}{l}\text { The functional cost of a dam consists of: the salaries of the } \\
\text { personnel, energy costs, as well as all those concerning the }\end{array}$ & 5 \\
\hline
\end{tabular}




\begin{tabular}{|l|l|c|}
\hline & maintenance of the whole plant. & \\
\hline $\begin{array}{l}E_{3}: \text { Land Reclamation } \\
\text { Needs/Requirements of } \\
\text { the Earth) }\end{array}$ & $\begin{array}{l}\text { There are great land reclamation needs at a well chosen region, } \\
\text { depending directly on the size of the dam. }\end{array}$ & 3 \\
\hline $\begin{array}{l}\text { TECHNICAL- } \\
\text { FUNCTIONAL }\end{array}$ & High functionality. & 9 \\
\hline$T_{1}:$ Functioning & Dams are used worldwide and are highly reliable. & 9 \\
\hline $\begin{array}{l}T_{2}: \text { Existing Experience }- \\
\text { Reliability }\end{array}$ & $\begin{array}{l}\text { The adjustability of a dam to regional characteristics can be } \\
\text { achieved, provided that the site selection study took into } \\
\text { consideration the regions special characteristics }\end{array}$ & 7 \\
\hline $\begin{array}{l}T_{3}: \text { Adjustability to Local } \\
\text { Conditions }\end{array}$ & $\begin{array}{l}\text { Provided that all the parameters concerning any periodic } \\
\text { changes have been taken into consideration, such as flood } \\
\text { fluxes, as far as these can be predicted, the method of water } \\
\text { concentrating by constructing a dam may be flexible. }\end{array}$ & 7 \\
\hline$T_{4}:$ Flexibility & $\begin{array}{l}\text { Average life span, which depends directly on the solids flux of } \\
\text { the river. }\end{array}$ & 5 \\
\hline$T_{5}:$ Life Span &
\end{tabular}

\section{- $5^{\text {th }}$ Step}

In this fifth step, all the grades that have been given in the previous step ( $4^{\text {th }}$ step) for each criterion in particular, they are multiplied by the relevant factor of significance that each one has in the group of criteria they belong to. Further on, the results of the multiplications are added. Consequently, the final marking of each group is calculated as it is presented in the following table.

\begin{tabular}{|c|c|c|c|}
\hline Criteria of Comparative Evaluation & $\begin{array}{l}\text { Factor(s) of } \\
\text { Significance }\end{array}$ & $\begin{array}{c}\text { SCENARIO 1 } \\
\text { Artificial Recharge }\end{array}$ & $\begin{array}{c}\text { SCENARIO } 2 \\
\text { Dam }\end{array}$ \\
\hline \multicolumn{4}{|l|}{ SOCIAL $(0.25)$} \\
\hline $\begin{array}{l}S_{1}: \text { Concordance with the existing Leg- } \\
\text { islation }\end{array}$ & 0.25 & 10 & 5 \\
\hline $\begin{array}{l}S_{2}: \text { Application of possible Legislative } \\
\text { Priorities }\end{array}$ & 0.30 & 10 & 7 \\
\hline$S_{3}:$ Social Approval & 0.30 & 8 & 7 \\
\hline$S_{4}:$ New Jobs Opportunities & 0.15 & 5 & 7 \\
\hline \multicolumn{4}{|l|}{ ENVIRONMENTAL $(0.30)$} \\
\hline EN ${ }_{1}:$ Environmental Impact & 0.40 & 7 & 1 \\
\hline$E N_{2}:$ Aesthetics & 0.30 & 8 & 4 \\
\hline$E N_{3}:$ Potential Dangers & 0.30 & 8 & 5 \\
\hline \multicolumn{4}{|l|}{ ECONOMIC $(0.25)$} \\
\hline$E_{l}:$ Initial Cost of Investment & 0.40 & 8 & 1 \\
\hline $\begin{array}{l}E_{2}: \text { Functional Cost-Cost of Mainte- } \\
\text { nance }\end{array}$ & 0.40 & 7 & 5 \\
\hline $\begin{array}{l}\text { E3: Land Reclamation } \\
\text { (Needs/Requirements of the Earth) }\end{array}$ & 0.20 & 10 & 3 \\
\hline \multicolumn{4}{|l|}{$\begin{array}{l}\text { TECHNICAL - FUNCTIONAL } \\
(0.20)\end{array}$} \\
\hline$T_{l}:$ Functioning & 0.30 & 9 & 9 \\
\hline$T_{2}$ : Existing Experience - Reliability & 0.30 & 7 & 9 \\
\hline$T_{3}:$ Adjustability to Local Conditions & 0.15 & 9 & 7 \\
\hline$T_{4}:$ Flexibility & 0.15 & 9 & 7 \\
\hline$T_{5}:$ Life Span & 0.10 & 10 & 5 \\
\hline
\end{tabular}




\begin{tabular}{|l|c|c|c|}
\hline \multicolumn{1}{|c|}{ Criteria of Comparative Evaluation } & $\begin{array}{c}\text { Factor(s) of } \\
\text { Significance }\end{array}$ & $\begin{array}{c}\text { SCENARIO 1 } \\
\text { Artificial Recharge }\end{array}$ & $\begin{array}{c}\text { SCENARIO 2 } \\
\text { Dam }\end{array}$ \\
\hline SOCIAL (0.25) & 0.25 & $\mathbf{8 . 6 5}$ & $\mathbf{6 . 5}$ \\
\hline $\begin{array}{l}S_{1}: \text { Concordance with the existing Leg- } \\
\text { islation }\end{array}$ & 0.30 & 2.5 & 1.25 \\
\hline $\begin{array}{l}S_{2}: \text { Application of possible Legislative } \\
\text { Priorities }\end{array}$ & & 3 & 2.1 \\
\hline$S_{3}:$ Social Approval & 0.30 & 2.4 & 2.1 \\
\hline$S_{4}:$ Possibility of New Posts of Work & 0.15 & 0.75 & 1.05 \\
\hline ENVIRONMENTAL (0.30) & & 7.6 & 3.1 \\
\hline EN $:$ Affecting the Environment & 0.40 & 2.8 & 0.4 \\
\hline EN $:$ Aesthetics & 0.30 & 2.4 & 1.2 \\
\hline EN $:$ Potential Dangers & 0.30 & 2.4 & 1.5 \\
\hline ECONOMIC $(\mathbf{0 . 2 5})$ & & $\mathbf{8}$ & $\mathbf{3}$ \\
\hline$E_{1}:$ Initial Cost of Investment & 0.40 & 3.2 & 0.4 \\
\hline $\begin{array}{l}E_{2}: \text { Functional Cost }- \text { Cost of Mainte- } \\
\text { nance }\end{array}$ & 0.40 & 2.8 & 2 \\
\hline$E_{3}:$ Land/Property acquisition & 0.20 & 2 & 0.6 \\
\hline $\begin{array}{l}\text { TECHNICAL - FUNCTIONAL } \\
(\mathbf{0 . 2 0})\end{array}$ & & $\mathbf{8 . 5}$ & $\mathbf{8}$ \\
\hline$T_{1}:$ Functionality & 0.30 & 2.7 & 2.7 \\
\hline$T_{2}:$ Existing Experience - Reliability & 0.30 & 2.1 & 2.7 \\
\hline$T_{3}:$ Adjustability to Local Conditions & 0.15 & 1.35 & 1.05 \\
\hline$T_{4}:$ Flexibility & 0.15 & 1.35 & 1.05 \\
\hline$T_{5}:$ Life Span & 0.10 & 1 & 0.5 \\
\hline
\end{tabular}

- $6^{\text {th }}$ Step

The grading of each group of criteria which took place in the previous step ( $5^{\text {th }}$ step) is multiplied by the relevant factor of significance according to the overall/holistic function $\left(1^{\text {st }}\right.$ step $)$ and finally the overall grade of each scenario is calculated, with which the final selection of a scenario will be made.

\begin{tabular}{|l|c|c|}
\hline GROUP OF CRITERIA & $\begin{array}{c}\text { SCENARIO 1 } \\
\text { Artificial Recharge }\end{array}$ & $\begin{array}{c}\text { SCENARIO 2 } \\
\text { Dam }\end{array}$ \\
\hline SOCIAL & 2.1625 & 1.625 \\
\hline ENVIRONMENTAL & 2.28 & 0.93 \\
\hline ECONOMIC & 2 & 0.75 \\
\hline TECHNICAL - & 1.7 & 1.6 \\
FUNCTIONAL & $\mathbf{8 . 1 4 2 5}$ & $\mathbf{5 . 2 1 7 5}$ \\
\hline TOTAL & & \\
\hline
\end{tabular}

\section{The Results of the Multi-Criteria Analysis}

The evaluation of the suggested scenarios, according to the above Multi-Criteria analysis has the following results:

The method of artificial recharge has the highest grading (Artificial Recharge $=8.1425$, Dam Construction $=5.2175)$, therefore the classification of the choices is the following: A1 = Artificial Recharge and A2 = Dam Constructing. Projects combining aquifers artificial recharge with flood preventing protection schemes are completely aligned with the principles of "Sustainable Development".

\section{References}

Hokkanen, J., and Salminen, P., 1994. The choice of a solid waste management system by using the ELECTRE III decision-aid method. In M. Paruccini (ed.), Applying Multiple Criteria Aid 
for Decision to Environmental Management. Kluwer Academic Publishers, Boston, 111$155 \mathrm{pp}$.

Hwang, C. L., and Masud, A. S. M., 1979. Multiple objective decision making - methods and applications. New York, Springer.

Janssen, R., and Nijkamp, P., 1984. A multiple criteria evaluation topology of environmental management problems. In Y.H. Yacove and V. Chankong (eds.), Proceedings of Decision Making with Multiple Objectives. Cleveland, Ohio, 495-514pp.

Jankowski, P., 1995. Integrating geographical information systems and multiple criteria decisionmaking methods, International Journal of Geographical Information Systems, 9(3), 251273

Janssen, R., Nijkamp, P., and Voogd, H., 1984. Environmental Policy analysis: which method for which problem? Revue d'Economie Regionale et Urbaine, 5, 839-855.

Korhonen, P.J., 1987. A visual interactive support system for multiple criteria decision making, Belgian Journal of Operations Research, Statistics and Computer Science, 27, 3-15.

Mavrotas, G., Diakoulaki, D., and Asimacopoulos, D., 1994. Energy planning and trade-o•s between environmental and economic criteria. In M. Paruccini (ed.), Applying Multiple Criteria Aid for Decision to Environmental Management. Kluwer Academic Publishers, Boston, 187-198 pp.

Munda, G., Nijkamp, P., and Rietveld, P., 1994. Qualitative multicriteria evaluation for environmental management, Ecological Economics, 10 (2), 97-112.

Nijkamp, P., 1989. Multicriteria analysis: "a decision support system for sustainable environmental management". In F. Archibugi and P. Nijkamp (eds), Economy and Ecology Towards Sustainable Development. Kluwer Academic Pub- lishers, London, 203-259 pp.

RAC., 1992. Multi-criteria analysis as a resource assessment tool, Resource Assessment Commission, Research Paper No. 6, Canberra.

Romero, C., and Rehman, T., 1989. Multiple Criteria Analysis for Agricultural Decisions, Elsevier, Amsterdam.

Stewart, T., and Scott, L., 1995. A scenario-based framework for multicriteria decision analysis in water resources planning. Water Resources Research, 31 (11), 2835-2843. 